\title{
STRATEGI CAMAT DALAM PENGELOLAAN SAMPAH DI KECAMATAN JATINANGOR KABUPATEN SUMEDANG PROVINSI JAWA BARAT
}

\author{
Oleh \\ Leo Amaltheus Laia ${ }^{1}$, \\ Etin Indrayani' ${ }^{2}$, Muh. Ilham ${ }^{3}$ \\ 1) Institut Pemerintahan Dalam Negeri \\ Program Magister Terapan Studi Pemerintahan Daerah Institut Pemerintahan Dalam Negeri \\ leolaia2016@gmail.com \\ 2,3) Institut Pemerintahan Dalam Negeri
}

\begin{abstract}
This research focused to describe Sub-District Head strategy in waste management in Jatinangor 1 District, Sumedang Regency. Analyzing troubleshooting issues in Jatinangor District which are still not yet in good management which is lack of supporting infrastructure facilities like temporary waste disposal, and lack of community awareness in waste management. The purpose of this research is to know the Sub-District Head strategy in managing waste in Jatinangor District, Sumedang Regency.

This research is using strategy theory in the implementation of Rangkuti (2014) and doing SWOT and Litmus Test analysis for determining the strategy. This research using a Qualitative Theory with a Descriptive Approach with a Qualitative Approach and using inductive data analysis. Data collection techniques used are through observation, documentation and triangulation interviews.

The results of the research shows that strategy of Sub-District Head in management of waste in Jatinangor District, Sumedang Regency still hasn't runned well. And then with existence of strength as well as the opportunities are owned by the district of Jatinangor, could become the supporting side to solve any kind of threat and weaknesses in the implementation of managing waste.
\end{abstract}

Keywords: strategy, management, waste

\section{ABSTRAK}

$\mathrm{P}_{\mathrm{s}}^{\mathrm{e}}$ enelitian ini memfokuskan untuk mendeskripsikan strategi Camat dalam pengelolaan sampah di Kecamatan Jatinangor Kabupaten Sumedang, menganalisis permasalahan pengelolaan sampah di Kecamatan Jatinangor, yaitu masih belum dikelola dengan baik, kurangnya sarana prasarana pendukung seperti tempat pembuangan sampah sementara, kurangnya kesadaran masyarakat dalam pengelolaan sampah. Tujuan dari penelitian ini ialah untuk mengetahui Strategi Camat dalam pengelolaan sampah di Kecamatan Jatinangor Kabupaten Sumedang.

Penelitian ini menggunakan teori Strategi dalam pelaksanaan oleh Rangkuti (2014) serta melakukan analisis SWOT dan Litmus Test untuk menentukan Strategi. Penelitian ini 
menggunakan teori Kualitatif dengan pendekatan deskriptif dengan pendekatan kualitatif dan menggunakan analisis data secara induktif. Adapun Teknik pengumpulan data yang digunakan, yaitu melalui wawancara, observasi, dokumentasi dan triangulasi.

Hasil penelitian menunjukkan bahwa strategi Camat dalam pengelolaan sampah di Kecamatan Jatinangor Kabupaten Sumedang masih belum berjalan dengan baik, maka dengan adanya kekuatan serta adanya peluang yang dimiliki oleh Kecamatan Jatinangor dapat menjadi penunjang dalam mengatasi berbagai ancaman serta kelemahan dalam kegiatan pengelolaan sampah.

Kata kunci: strategi, pengelolaan, sampah

\section{PENDAHULUAN}

$\mathrm{B}$ erdasarkan Undang-Undang Nomor 18 Tahun 2008 tentang pengolahan sampah, diharapkan pelaksanaan penanganan sampah di Indonesia bisa diatasi dengan baik, dilakukan dengan penyadaran, pelatihan serta pendampingan masyarakat, agar warga ikut berpartisipasi dalam merencanakan, mengelola serta memanfaatkan sampahnya dengan baik dan efesien. Sampah ada dua jenis, yaitu sampah rumah tangga dan sampah sejenis rumah tangga. Sampah rumah tangga adalah sampah yang berasal dari kegiatan sehari-hari dalam rumah tangga yang tidak termasuk tinja dan sampah spesifik, sedangkan sampah sejenis rumah tangga adalah sampah rumah tangga yang berasal dari Kawasan komersial, Kawasan khusus, Kawasan industri, fasilitas sosial, fasilitas umum, dan/atau fasilitas lainnya.

Salah satu yang menjadi bagian dari urusan pemerintah berdasarkan UndangUndang No 23 Tahun 2014, bahwa urusan pemerintah wajib yang diselenggarakan oleh pemerintah daerah terbagi menjadi urusan pemerintah yang berkaitan dengan pelayanan dasar dan urusan pemerintah yang tidak berkaitan dengan pelayanan dasar. Dalam urusan wajib non pelayanan dasar salah satu yang menjadi bagian dari urusan wajib pemerintah adalah lingkungan hidup dalam hal ini menjadi tanggung jawab pemerintah daerah dalam menjaga lingkungan hidup.
Dalam menjalankan dan menjabarkan undang-undang tersebut di atas, maka pemerintah Kabupaten Sumedang membuat suatu kebijakan, yaitu Peraturan Bupati Sumedang Nomor 12 Tahun 2019 tentang kebijakan dan strategi daerah kabupaten sumedang dalam pengelolaan sampah rumah tangga dan sampah sejenis rumah tangga dengan tujuan untuk mewujudkan pengelolaan sampah rumah tangga dan sejenis rumah tangga secara terencana, terpadu dan program dalam rangka mewujudkan kabupaten sumedang bebas sampah tahun 2025.

Pemerintah Daerah Kabupaten Sumedang dalam mengatasi persoalan sampah yang semakin banyak, juga merumuskannya dalam Peraturan Daerah Kabupaten Sumedang Nomor 2 Tahun 2014 tentang Pengelolaan Sampah Rumah Tangga dan Sampah Sejenis Sampah Rumah Tangga di Kabupaten Sumedang Upaya tersebut bertujuan untuk menangani sampah yang ada di Kabupaten Sumedang sehingga mengurangi volume sampah yang semakin hari semakin bertambah dan mencemari lingkungan serta berdampak negatif terhadap kesehatan dan keindahan lingkungan di Kabupaten Sumedang.

Berdasarkan peraturanBupatiSumedang Nomor 55 Tahun 2009 tentang pelimpahan sebagian kewenangan pemerintahan dari bupati kepada camat di lingkungan pemerintahan kabupaten Sumedang, yaitu pada bidang lingkungan hidup di mana camat memiliki kewenangan dalam melakukan koordinasi dalam pengelolaan sampah dari tempat pembuangan sampah ke tempat 
pembuangan sampah akhir dan melakukan pengawasan pada pengelolaan sampah oleh masyarakat.

Penduduk Kabupaten Sumedang berdasarkan proyeksi kependudukan tahun 2017 sebanyak 1.146 .435 jiwa yang terdiri atas 570.808 jiwa penduduk laki-laki dan 575.627 jiwa penduduk perempuan, pertumbuhan penduduk ini mengalami pertumbuhan sebesar 0,38 persen.

Kecamatan Jatinangor lebih besar dibandingkan dengan kecamatan lain di Kabupaten sumedang. Dengan perkembangan yang semakin pesat, perkembangan pembangunan dan pertambahan penduduk yang cukup tinggi di Kabupaten Sumedang akan menimbulkan tuntutan besar terhadap pemenuhan fasilitas masyarakat.

Luas wilayah suatu daerah berpengaruh besar terhadap kepadatan penduduk hal ini bisa kita lihat dari luas wilayah yang ada di Kabupaten Sumedang, yaitu 1.522,20 $\mathrm{Km}^{2}$. Kepadatan penduduk di Kabupaten sumedang tahun 2018 mencapai 753 jiwa/ km2. Kepadatan penduduk di 26 kecamatan cukup beragam dengan kepadatan penduduk tertinggi terletak di Kecamatan Jatinangor dengan kepadatan sebesar 4.348 jiwa/km2 dan terendah di Jatigede sebesar 215 jiwa/ $\mathrm{km} 2$.

Berdasarkan data Badan Lingkungan hidup bahwa produksi sampah rumah tangga di Kecamatan Jatinangor setiap harinya sangat banyak, yaitu $\pm 0,4 \mathrm{~kg} /$ orang. Sehingga kalau dilihat dari jumlah penduduk sekitar 113.913 jiwa maka produksi sampah rumah tangga dalam sehari bisa mencapai sekitar $44.000 \mathrm{~kg}$ atau sekitar 44 ton. Sarana pengangkutan sampah yang disediakan oleh Dinas Lingkungan Hidup dan Kehutanan hanya 1 truk, dan berfungsi untuk mengangkut sampah dari Kecamatan Tanjungsari, Kecamatan Jatinangor hingga ke Kecamatan Cimanggung. sehingga tumpukan sampah yang berada di TPS atau di pinggir jalan raya tidak semuanya dapat diangkut oleh petugas dikarenakan keterbatasan waktu dan jumlah armada yang tersedia.

\section{KAJIAN PUSTAKA}

\section{Strategi}

Menurut Rangkuti bahwa "Strategi adalah merupakan alat mencapai tujuan". Dalam perkembangannya, konsep mengenai strategi terus berkembang. Hal ini dapat ditunjukkan oleh adanya perbedaan konsep mengenai strategi selama 30 tahun terakhir.

Menurut Rangkuti (2014:83), alat yang digunakan untuk menyusun faktor-faktor strategi organisasi adalah matriks SWOT (Streng, weaknes, opportunities, threats) Matriks ini dapat menggambarkan secara jenis bagaimana peluang ancaman eksternal yang dihadapi perusahaan dapat disesuaikan dengan kekuatan dan kelemahan yang dimilikinya.

\section{Urusan Penanggulangan Sampah}

Pengelolaan sampah menjadi amanat Undang-Undang Nomor 18 Tahun 2018 tentang pengolahan sampah, peraturan pemerintah (PP) 81 Tahun 2012 tentang pengelolaan sampah rumah tangga dan sampah sejenis rumah tangga, dan Peraturan Presiden (Perpres) No. 97 Tahun 2017 tentang kebijakan dan strategi nasional pengelolaan sampah rumah tangga dan sampah sejenis rumah tangga, pemerintah menetapkan kebijakan dan strategi pengelolaan sampah nasional (Jakstranas) Menanggapi semakin meningkatnya jumlah sampah sampah khususnya sampah plastik, pemerintah semakin serius dengan cara menggandeng World Economic Forum (WEF), pemerintah menggalakkan program "Indonesia bebas plastik" dengan cara mengurangi sampah sebesar $70 \%$ di tahun 2020. Demi melancarkan program tersebut pemerintah bekerja sama dengan pengusaha, masyarakat, dan berbagai instansi pemerintahan. 


\section{Camat}

Camat adalah perangkat daerah kabupaten dan daerah kota dan bukan lagi kepala wilayah administrasi pemerintahan, dengan demikian camat bukan lagi penguasa tunggal yang berfungsi sebagai administrator pemerintahan, pembangunan dan kemasyarakatan, akan tetapi merupakan pelaksana sebagian wewenang yang dilimpahkan oleh bupati/wali kota (Sadu Wasistiono, 2009:33)

\section{Sampah dan Pengelolaan Sampah}

Sampah adalah bahan yang tidak mempunyai nilai atau tidak berharga untuk maksud biasa atau utama dalam pembuatan atau pemakaian barang rusak atau bercacat dalam pembuatan manufaktur atau materi berkelebihan atau ditolak atau dibuang (Hendargo, 1994) Definisi lain dikemukakan oleh Hadiwiyono (1983), sampah adalah sisa-sisa bahan yang telah mengalami perlakuan baik telah diambil bagian utamanya, telah mengalami pengolahan, dan sudah tidak bermanfaat, dari segi ekonomi sudah tidak ada harganya serta dari segi lingkungan dapat menyebabkan pencemaran atau gangguan kelestarian alam.

Sementara itu, pengelolaan adalah pengendalian dan pemanfaatan semua faktor dan sumber daya, yang menurut suatu perencanaan diperlukan untuk mencapai atau menyelesaikan suatu tujuan kerja yang tertentu (Prajudi, 1980).

Pada Pasal 1 ayat (5) Undang-Undang Nomor 18 Tahun 2008 tentang Pengelolaan
Sampah menyebutkan bahwa "Pengelolaan sampah adalah kegiatan yang sistematis, menyeluruh dan berkesinambungan yang meliputi pengurangan dan penanganan sampah.

\section{METODE PENELITIAN}

Metode penelitian kualitatif yang digunakan dengan metode deskriptif, dinilai sesuai untuk digunakan dalam penelitian. Karena dalam kegiatan penelitian ini dilakukan berdasarkan fakta-fakta yang ada di lapangan yang kemudian dituangkan dalam bentuk kata-kata. Tentunya metode deskriptif kualitatif akan dapat menyampaikan gambaran berdasarkan fakta-fakta dengan jelas, teliti dan lengkap. Sedangkan untuk analisis tingkat lanjut sesuai dengan penelitian guna merumuskan strategi yang dilakukan untuk pengelolaan sampah maka penulis menggunakan analisis SWOT.

\section{HASIL DAN PEMBAHASAN}

Strategi Camat dalam Pengelolaan Sampah di Kecamatan Jatinangor Kabupaten Sumedang Provinsi Jawa Barat Menggunakan Matriks Analisis SWOT dan Uji Litmus test

Penentuan strategi dilakukan
menggunakan analisis SWOT melalui
pembobotan analisis faktor Internal (IFAS)
dan analisis faktor eksternal (EFAS), setelah
dilakukan penentuan strategi kemudian
dilakukan uji untuk mengetahui sejauh
mana tingkat strategis isu tersebut dengan
menggunakan uji Litmus test.

Penentuan strategi dilakukan menggunakan analisis SWOT melalui pembobotan analisis faktor Internal (IFAS) dan analisis faktor eksternal (EFAS), setelah dilakukan penentuan strategi kemudian mana tingkat strategis isu tersebut dengan

Tabel 1. Matriks Ifas

\begin{tabular}{|c|c|c|c|c|c|c|c|c|c|c|c|c|c|}
\hline \multirow[t]{2}{*}{ No. } & \multirow{2}{*}{ Faktor-faktor strategi Internal } & \multicolumn{4}{|c|}{ Bobot } & \multicolumn{4}{|c|}{ Rating } & \multicolumn{4}{|c|}{ Bobot $x$ Rating } \\
\hline & & IF1 & IF2 & IF3 & IF4 & IF1 & IF2 & IF3 & IF4 & IF1 & IF2 & IF3 & IF4 \\
\hline & Kekuatan: & & & & & & & & & & & & \\
\hline 1. & $\begin{array}{l}\text { Dukungan peraturan atau dasar } \\
\text { hukum pengelolaan sampah }\end{array}$ & 1,0 & 1,0 & 1,0 & 1,0 & 4 & 4 & 4 & 4 & 4 & 4 & 4 & 4 \\
\hline
\end{tabular}




\begin{tabular}{|c|c|c|c|c|c|c|c|c|c|c|c|c|c|}
\hline 2. & $\begin{array}{l}\text { Komunitas peduli sampah } \\
\text { jatinangor membantu pembersihan } \\
\text { dan pengangkutan sampah }\end{array}$ & 1,0 & 1,0 & 0,9 & 1,0 & 4 & 4 & 4 & 4 & 4 & 4 & 3,6 & 4 \\
\hline 3. & $\begin{array}{l}\text { Komitmen organisasi dibangun dari } \\
\text { rasa kekeluargaan }\end{array}$ & 0,8 & 1,0 & 1,0 & 0,7 & 3 & 4 & 4 & 3 & 2,4 & 4 & 4 & 2,1 \\
\hline 4. & $\begin{array}{l}\text { Loyalitas pegawai yang mendukung } \\
\text { kegiatan pengelolaan sampah sudah } \\
\text { baik }\end{array}$ & 0,9 & 1,0 & 1,0 & 0,8 & 3 & 4 & 3 & 3 & 2,7 & 4 & 3 & 2,4 \\
\hline \multirow[t]{2}{*}{5.} & $\begin{array}{l}\text { Kawasan Pendidikan menjadi } \\
\text { pendukung dalam pengelolaan } \\
\text { sampah }\end{array}$ & 1,0 & 0,8 & 0,9 & 1,0 & 4 & 4 & 3 & 4 & 4 & 2,4 & 3,6 & 4 \\
\hline & Kelemahan: & & & & & & & & & & & & \\
\hline 1. & $\begin{array}{l}\text { Terbatasnya sarana dan prasarana } \\
\text { sehingga pengelolaan sampah belum } \\
\text { dijalankan secara maksimal }\end{array}$ & 0,7 & 0,7 & 0,7 & 0,6 & 1 & 2 & 2 & 1 & 0,7 & 1,4 & 1,4 & 0,6 \\
\hline 2. & $\begin{array}{l}\text { Kurangnya sosialisasi mengenai } \\
\text { pengelolaan sampah yang baik } \\
\text { kepada warga di setiap desa }\end{array}$ & 0,8 & 0,8 & 0,7 & 0,7 & 2 & 2 & 2 & 2 & 1,6 & 1.6 & 1,4 & 1,4 \\
\hline 3. & $\begin{array}{l}\text { Pemanfaatan teknologi yang belum } \\
\text { optimal dalam pengelolaan sampah }\end{array}$ & 0,6 & 0,7 & 0,7 & 0,6 & 3 & 2 & 3 & 3 & 1,8 & 1,4 & 2,1 & 1,8 \\
\hline 4. & $\begin{array}{l}\text { Kesadaran masyarakat dalam } \\
\text { pengelolaan sampah masih rendah }\end{array}$ & 0,8 & 0,7 & 0,7 & 0,8 & 1 & 2 & 2 & 3 & 0,8 & 1,4 & 1,4 & 2,4 \\
\hline 5. & $\begin{array}{l}\text { Kekurangan Personil atau petugas } \\
\text { dalam pengelolaan sampah }\end{array}$ & 0,6 & 0,7 & 0,7 & 0,6 & 1 & 2 & 2 & 1 & 0,6 & 1,4 & 1,4 & 0,6 \\
\hline
\end{tabular}

Sumber: Rangkuti (diolah oleh Peneliti)

Tabel 2. Matriks Efas

\begin{tabular}{|c|c|c|c|c|c|c|c|c|c|c|c|c|}
\hline \multirow[b]{2}{*}{ Faktor-Faktor } & \multicolumn{4}{|c|}{ Bobot } & \multicolumn{4}{|c|}{ Rating } & \multicolumn{4}{|c|}{ Bobot x Rating } \\
\hline & IF1 & IF2 & IF3 & IF4 & IF1 & IF2 & IF3 & IF4 & IF1 & IF2 & IF3 & IF4 \\
\hline \multicolumn{13}{|l|}{ Peluang: } \\
\hline 1. Dukungan Pemerintah & 1,0 & 0,9 & 0,9 & 0,9 & 3 & 4 & 3 & 4 & 3 & 3,6 & 2,7 & 3,6 \\
\hline $\begin{array}{l}\text { 2. Adanya pokja air minum dan } \\
\text { pelestarian lingkungan mendukung } \\
\text { kegiatan pengelolaan sampah }\end{array}$ & 0,9 & 1,0 & 0,9 & 0,8 & 4 & 4 & 4 & 3 & 3,6 & 4 & 3,6 & 2,4 \\
\hline $\begin{array}{l}\text { 3. Kerja sama antar sektor yang akan } \\
\text { dilakukan oleh pemerintah daerah } \\
\text { maupun swasta dalam pengelolaan } \\
\text { sampah }\end{array}$ & 0,9 & 0,8 & 0,8 & 0,8 & 4 & 4 & 3 & 3 & 3,6 & 3,2 & 2,4 & 2,4 \\
\hline 4. Inovasi yang terus berkembang & 0,9 & 0,9 & 1,0 & 1,0 & 4 & 4 & 4 & 4 & 3,6 & 3,6 & 4 & 4 \\
\hline $\begin{array}{l}\text { 5. Pengelolaan sampah mempunyai nilai } \\
\text { dan menjadi peluang usaha }\end{array}$ & 0,1 & 0,9 & 0,8 & 0,8 & 4 & 4 & 3 & 3 & 4 & 3,6 & 2,4 & 2,4 \\
\hline
\end{tabular}

\section{Ancaman:}

\begin{tabular}{lllllllllllll}
\hline 1. Produksi sampah meningkat & 1,0 & 1,0 & 0,9 & 1,0 & 2 & 2 & 2 & 3 & 2 & 2 & 1,8 & 3 \\
\hline
\end{tabular}




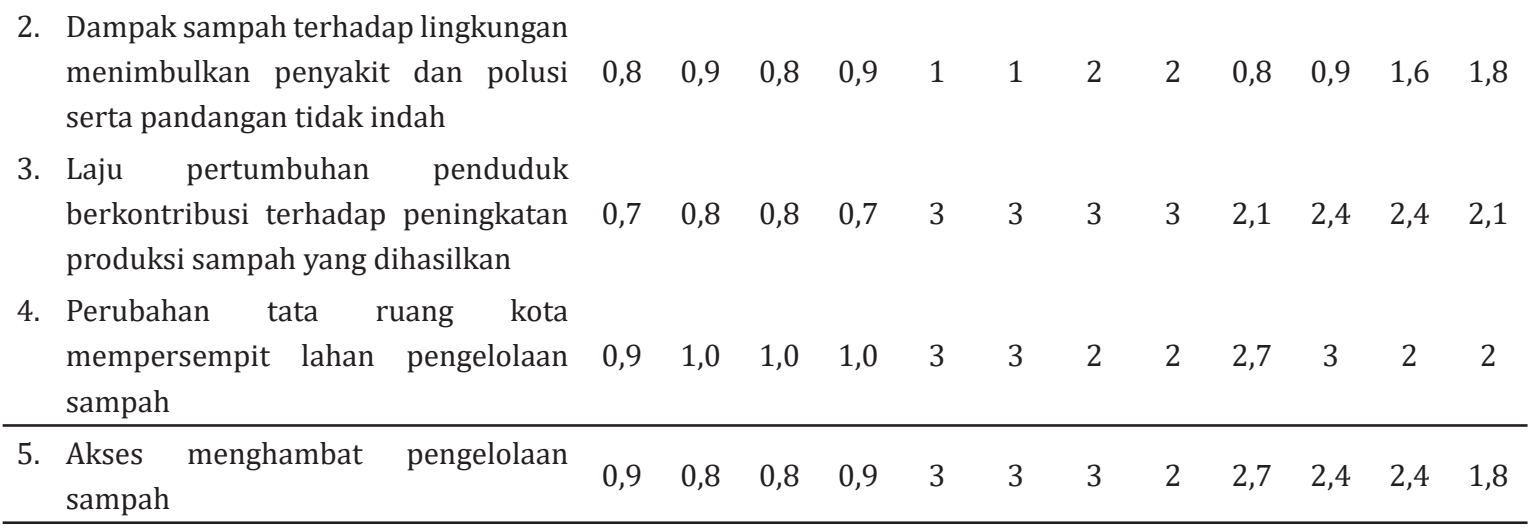

Sumber: Rangkuti (diolah oleh Peneliti)

Keterangan (Tabel 1 dan 2):

a. IF 1 = Informan 1 = Camat Jatinangor

b. IF2 = Informan 2 = Kepala Bidang Persampahan Lingkungan Hidup dan

Kehutanan Kabupaten Sumedang

c. IF3 = Informan $3=$ Kepala UPTD persampahan wilayah Jatinangor

d. IF4 = Informan $4=$ Ketua Komunita Peduli Sampah Jatinangor (KPSJ)

Berdasarkan pembobotan dan pemberian skor yang dilakukan oleh keempat informan di atas maka diperlukan penentuan rata-rata skor bobotnya. Hasil perhitungan penentuan ratarata skor dapat dilihat pada tabel berikut.

Tabel 3. Rata-rata Bobot Faktor-Faktor Strategi Internal

\begin{tabular}{|c|c|c|c|c|c|c|}
\hline \multirow{3}{*}{ No. } & \multirow{2}{*}{$\begin{array}{c}\text { Faktor-Faktor Strategi } \\
\text { Internal }\end{array}$} & \multicolumn{4}{|c|}{ Bobot $x$ Rating } & \multirow{2}{*}{ Rata-Rata } \\
\hline & & IF1 & IF2 & IF3 & IF4 & \\
\hline & \multicolumn{6}{|l|}{ Kekuatan (Lihat tabel 1) } \\
\hline 1 & Kekuatan Nomor 1 & 4 & 4 & 4 & 4 & 4 \\
\hline 2 & Kekuatan Nomor 2 & 4 & 4 & 3,6 & 4 & 3,9 \\
\hline 3 & Kekuatan Nomor 3 & 2,4 & 4 & 4 & 2,1 & 3,12 \\
\hline 4 & Kekuatan Nomor 4 & 2,7 & 4 & 3 & 2,4 & 3,02 \\
\hline \multirow[t]{2}{*}{5} & Kekuatan Nomor 5 & 4 & 2,4 & 3,6 & 4 & 3,5 \\
\hline & \multicolumn{6}{|l|}{ Kelemahan (Lihat Tabel 1) } \\
\hline 1 & Kekuatan Nomor 1 & 0,7 & 1,4 & 1,4 & 0,6 & 1,02 \\
\hline 2 & Kekuatan Nomor 2 & 1,6 & 1.6 & 1,4 & 1,4 & 1,5 \\
\hline 3 & Kekuatan Nomor 3 & 1,8 & 1,4 & 2,1 & 1,8 & 1,78 \\
\hline 4 & Kekuatan Nomor 4 & 0,8 & 1,4 & 1,4 & 2,4 & 1,5 \\
\hline \multirow[t]{2}{*}{5} & Kekuatan Nomor 5 & 0,6 & 1,4 & 1,4 & 0,6 & 1 \\
\hline & TOTAL & & & & & 2,43 \\
\hline
\end{tabular}

Sumber: Diolah Peneliti,2019 
Tabel 4 Rata-rata Bobot Faktor-Faktor Strategi Eksternal

\begin{tabular}{|c|c|c|c|c|c|}
\hline \multirow{2}{*}{$\begin{array}{c}\text { Faktor-Faktor Strategi } \\
\text { Eksternal }\end{array}$} & \multicolumn{4}{|c|}{ Bobot x Rating } & \multirow[t]{2}{*}{ Rata-Rata } \\
\hline & IF1 & IF2 & IF3 & IF4 & \\
\hline \multicolumn{6}{|l|}{ Peluang (Lihat tabel 2) } \\
\hline Kekuatan Nomor 1 & 3 & 3,6 & 2,7 & 3,6 & 3,22 \\
\hline Kekuatan Nomor 2 & 3,6 & 4 & 3,6 & 2,4 & 3,4 \\
\hline Kekuatan Nomor 3 & 3,6 & 3,2 & 2,4 & 2,4 & 2,9 \\
\hline Kekuatan Nomor 4 & 3,6 & 3,6 & 4 & 4 & 3,8 \\
\hline Kekuatan Nomor 5 & 4 & 3,6 & 2,4 & 2,4 & 3,1 \\
\hline \multicolumn{6}{|l|}{ Ancaman (Lihat Tabel 2) } \\
\hline Kekuatan Nomor 1 & 2 & 2 & 1,8 & 3 & 2,2 \\
\hline Kekuatan Nomor 2 & 0,8 & 0,9 & 1,6 & 1,8 & 1,27 \\
\hline Kekuatan Nomor 3 & 2,1 & 2,4 & 2,4 & 2,1 & 1,25 \\
\hline Kekuatan Nomor 4 & 2,7 & 3 & 2 & 2 & 2,42 \\
\hline Kekuatan Nomor 5 & 2,7 & 2,4 & 2,4 & 1,8 & 2 , \\
\hline TOTAL & & & & & 1,29 \\
\hline
\end{tabular}

Sumber: Diolah Peneliti,2019

Berdasarkan hasil perhitungan skor dan bobot pada tabel di atas, maka diperoleh jumlah total skor bobot faktor internal ialah 2,43 dan jumlah total rata-rata skor bobot faktor eksternal ialah 1,29. Pada rata-rata skor bobot faktor internal terdapat angka 2,43 yang menunjukkan bahwa strategi pengelolaan sampah di Kecamatan Jatinangor menunjukkan posisi internal yang cukup kuat (rentang skor 2,0-3,0 adalah rata-rata/ menengah) mengindikasikan posisi camat dalam melaksanakan strategi pengelolaan sampah cukup kuat, yang berarti sudah berpotensi mampu menggali kekuatan dan kelemahan untuk kemudian ditindaklanjuti.

Sementara itu, pada rata-rata skor bobot faktor eksternal terdapat angka 1,29 yang menunjukkan bahwa camat memiliki potensi untuk mampu merespons dengan baik peluang dan ancaman dalam strategi pengelolaan sampah di Kecamatan Jatinangor (dengan rentang skor 1,0-3,0 adalah menengah) Karena berada pada rentang skor 2,0-3,0 artinya menunjukkan potensi untuk mampu memanfaatkan peluang yang ada dengan baik serta menghindari segala ancaman yang muncul.
Berdasarkan hasil perumusan maka terdapat analisis SWOT sebanyak 20 (dua puluh) strategi yang digunakan dalam pembuatan Strategi Camat Dalam Pengelolaan Sampah di Kecamatan Jatinangor Kabupaten Sumedang Provinsi Jawa Barat. Adapun strategi yang dimaksud adalah sebagai berikut.

1. Membentuk Memorandum of Understanding (MOU) dengan Komunitas Peduli Sampah Jatinangor (KPSJ) sehingga dapat membantu pelaksanaan program sanitasi total berbasis masyarakat (STBM);

2. Mendukung dan menjalankan program Pokja Air Minum dan Penyehatan Lingkungan (AMPL) dalam pengelolaan sampah;

3. Membentuk bank sampah di tiap desa melalui kerja sama di sektor pemerintah dan swasta sesuai dengan peraturan yang berlaku;

4. Menciptakan inovasi-inovasi terbaru dalam pengelolaan sampah melalui kerja sama dengan sektor internal, sektor swasta, perguruan tinggi serta masyarakat; 
5. Memanfaatkan pengelolaan sampah dengan baik agar memiliki nilai ekonomi

6. Menyediakan Sarana prasarana pendukung dalam pengelolaan sampah;

7. Memfasilitasi pemanfaatan teknologi melalui pembinaan dan pelatihan pengelolaan sampah;

8. Melaksanakan program pengelolaan sampah dengan melengkapi sarana prasarana serta memaksimalkan pemanfaatan teknologi;

9. Menekan produksi sampah dengan penggunaan produk ramah lingkungan serta daur ulang sampah;

10. Berkomitmen untuk terus melakukan upaya perubahan dalam pengelolaan sampah;

11. Menekan produksi sampah dengan penggunaan produk ramah lingkungan serta daur ulang sampah;

12. Berkomitmen untuk terus melakukan upaya perubahan dalam pengelolaan sampah;

13. Mendukung dan memfasilitasi KPSJ dalam pengelolaan sampah guna menghindari dampak buruk sampah;

14. Memanfaatkan wilayah jatinangor sebagai kawasan pendidikan dalam pengelolaan sampah;
15. Meningkatkan kerja sama antara pemerintah, sektor terkait dan lembaga pendidikan dalam kegiatan pengelolaan sampah;

16. Memberikan pelatihan untuk meningkatkan keterampilan aparat dalam mengatasi permasalahan sampah;

17. Membina masyarakat untuk membiasakan diri memilah dan memanfaatkan sampah mulai dari lingkungan terkecil, yaitu tempat tinggal;

18. Mencanangkan program sosialisasi pengelolaan sampah dan dampak sampah;

19. Memanfaatkan teknologi dalam mengatasi kondisi lingkungan geografis yang kurang mendukung pengelolaan sampah;

20. Menstimulus masyarakat melalui kegiatan yang dapat mengembangkan kreativitas dan meningkatkan kesadaran lingkungan.

Berdasarkan hasil analisis SWOT diperoleh 20 isu-isu strategis yang kemudian telah diukur tingkat kestrategisannya menggunakan Litmus Test yang di berikan kepada informan yang bersifat homogen, yaitu Camat Jatinangor maka dapat diperoleh simpulan hasil Litmus Test sebagaimana sebagai berikut berikut.

Tabel 5 Rekapitulasi Litmus Test

\begin{tabular}{|c|c|c|c|}
\hline NO & Isu Strategis & $\begin{array}{l}\text { Total } \\
\text { Skor }\end{array}$ & Simpulan \\
\hline 1 & $\begin{array}{l}\text { Membentuk Memorandum of Understanding (MOU) dengan } \\
\text { Komunitas Peduli Sampah Jatinangor (KPSJ) sehingga dapat } \\
\text { membantu pelaksanaan program sanitasi total berbasis masyarakat } \\
\text { (STBM }\end{array}$ & 34 & Isu sangat strategis \\
\hline 2 & $\begin{array}{l}\text { Mendukung dan menjalankan program Pokja air minum dan } \\
\text { penyehatan lingkungan (AMPL) dalam pengelolaan sampah }\end{array}$ & 16 & Isu bersifat Operasional \\
\hline 3 & $\begin{array}{l}\text { Membentuk bank sampah di tiap Desa melalui kerja sama di sektor } \\
\text { pemerintah dan swasta sesuai dengan peraturan yang berlaku }\end{array}$ & 32 & Isu sangat strategis \\
\hline 4 & $\begin{array}{l}\text { Menciptakan inovasi-inovasi terbaru dalam pengelolaan sampah } \\
\text { melalui kerja sama sektor internal, sektor swasta, perguruan tinggi } \\
\text { serta masyarakat }\end{array}$ & 34 & Isu sangat strategis \\
\hline
\end{tabular}




\begin{tabular}{|c|c|c|c|}
\hline 5 & $\begin{array}{l}\text { Memanfaatkan pengelolaan sampah dengan baik agar memiliki } \\
\text { nilai ekonomis }\end{array}$ & 20 & Isu bersifat operasional \\
\hline 6 & $\begin{array}{l}\text { Menyediakan sarana prasarana pendukung dalam pengelolaan } \\
\text { sampah }\end{array}$ & 31 & isu sangat strategis \\
\hline 7 & Melaksanakan sosialisasi pengelolaan sampah kepada masyarakat & 31 & Isu sangat strategis \\
\hline 8 & $\begin{array}{l}\text { Memfasilitasi pemanfaatan teknologi melalui pembinaan dan } \\
\text { pelatihan }\end{array}$ & 33 & Isu sangat strategis \\
\hline 9 & Meningkatkan kesadaran masyarakat dalam pengelolaan sampah & 32 & Isu sangat strategis \\
\hline 10 & Meningkatkan personel dalam pelayanan pengelolaan sampah & 31 & Isu sangat strategis \\
\hline 11 & $\begin{array}{l}\text { Menekan produksi sampah dengan penggunaan produk ramah } \\
\text { lingkungan serta daur ulang sampah; }\end{array}$ & 22 & Isu cukup strategis \\
\hline 12 & $\begin{array}{l}\text { Berkomitmen untuk terus melakukan upaya perubahan dalam } \\
\text { pengelolaan sampah }\end{array}$ & 17 & Isu bersifat Operasional \\
\hline 13 & $\begin{array}{l}\text { Mendukung dan memfasilitasi Komunitas peduli sampah Jatinangor } \\
\text { dalam pengelolaan sampah guna menghindari dampak buruk } \\
\text { sampah; }\end{array}$ & 34 & Isu sangat strategis \\
\hline 14 & $\begin{array}{l}\text { Memanfaatkan wilayah Jatinangor sebagai kawasan pendidikan } \\
\text { dalam pengelolaan sampah geografis pengelolaan sampah }\end{array}$ & 30 & Isu Sangat strategis \\
\hline 15 & $\begin{array}{l}\text { Meningkatkan kerja sama antara pemerintah dan lembaga } \\
\text { pendidikan dalam kegiatan pengelolaan sampah rumah tangga; }\end{array}$ & 31 & Isu sangat strategis \\
\hline 16 & $\begin{array}{l}\text { Melaksanakan pelatihan untuk meningkatkan keterampilan aparat } \\
\text { dalam mengatasi permasalahan sampah }\end{array}$ & 29 & Isu cukup strategis \\
\hline 17 & $\begin{array}{l}\text { Membina masyarakat untuk membiasakan diri memilah dan } \\
\text { memanfaatkan sampah mulai dari lingkungan terkecil, yaitu tempat } \\
\text { tinggal; }\end{array}$ & 22 & Isu cukup strategis \\
\hline 18 & $\begin{array}{l}\text { Mencanangkan program sosialisasi pengelolaan sampah rumah } \\
\text { tangga dan dampak sampah; }\end{array}$ & 31 & Isu sangat strategis \\
\hline 19 & $\begin{array}{l}\text { Memanfaatkan teknologi dalam mengatasi kondisi lingkungan } \\
\text { geografis yang kurang mendukung pengelolaan sampah rumah } \\
\text { tangga; }\end{array}$ & 29 & Isu cukup strategis \\
\hline 20 & $\begin{array}{l}\text { Menstimulus masyarakat melalui kegiatan yang dapat } \\
\text { mengembangkan kreativitas dan meningkatkan kesadaran } \\
\text { lingkungan }\end{array}$ & 24 & Isu cukup strategis \\
\hline
\end{tabular}

Sumber: Diolah oleh peneliti, 2019

Berdasarkan hasil dari akumulasi perhitungan dengan menggunakan Litmus Test menghasilkan alternatif strategi, yaitu terdiri dari 12 (dua belas) isu sangat strategis dan lima isu cukup strategis dan tiga isu bersifat operasional yang dapat digunakan Camat dalam pengelolaan sampah di Kecamatan Jatinangor Kabupaten Sumedang Provinsi Jawa Barat, isu tersebut, yaitu sebagai berikut.

\section{Isu sangat strategis:}

1. Membentuk Memorandum of Understanding (MOU) dengan Komunitas Peduli Sampah Jatinangor (KPSJ) sehingga dapat membantu pelaksanaan program sanitasi total berbasis masyarakat (STBM;

2. Membentuk bank sampah di tiap Desa melalui kerja sama di sektor pemerintah dan swasta sesuai dengan peraturan yang berlaku; 
3. Menciptakan inovasi-inovasi terbaru dalam pengelolaan sampah melalui kerja sama sektor internal, sektor swasta, perguruan tinggi serta masyarakat;

4. Menyediakan sarana prasarana pendukung dalam pengelolaan sampah;

5. Melaksanakan sosialisasi pengelolaan sampah kepada masyarakat;

6. Memfasilitasi pemanfaatan teknologi melalui pembinaan dan pelatihan;

7. Meningkatkan kesadaran masyarakat dalam pengelolaan sampah;

8. Meningkatkan personel dalam pelayanan pengelolaan sampah;

9. Mendukung dan memfasilitasi Komunitas peduli sampah Jatinangor dalam pengelolaan sampah guna menghindari dampak buruk sampah;

10. Memanfaatkan wilayah Jatinangor sebagai kawasan pendidikan dalam pengelolaan sampah;

11. Meningkatkan kerja sama antara pemerintah dan lembaga pendidikan dalam kegiatan pengelolaan sampah rumah tangga;

12. Mencanangkan program sosialisasi pengelolaan sampah rumah tangga dan dampak sampah;

\section{Isu Cukup Strategis}

1. Menekan produksi sampah dengan penggunaan produk ramah lingkungan serta daur ulang sampah;

2. Melaksanakan pelatihan untuk meningkatkan keterampilan aparat dalam mengatasi permasalahan sampah;

3. Membina masyarakat untuk membiasakan diri memilah dan memanfaatkan sampah mulai dari lingkungan terkecil, yaitu tempat tinggal;

4. Memanfaatkan teknologi dalam mengatasi kondisi lingkungan geografis yang kurang mendukung pengelolaan sampah rumah tangga;
5. Menstimulus masyarakat melalui kegiatan yang dapat mengembangkan kreativitas dan meningkatkan kesadaran lingkungan;

\section{Isu bersifat operasional}

1. Mendukung dan menjalankan program Pokja air minum dan penyehatan lingkungan (AMPL) dalam pengelolaan sampah;

2. Memanfaatkan pengelolaan sampah dengan baik agar memiliki nilai ekonomi;

3. Berkomitmen untuk terus melakukan upaya perubahan dalam pengelolaan sampah.

\section{SIMPULAN}

Berdasarkan hasil penelitian Strategi Camat dalam Pengelolaan Sampah di Kecamatan Jatinangor Kabupaten Sumedang Provinsi Jawa Barat, bahwa pengelolaan sampah di Kecamatan Jatinangor masih belum berjalan dengan baik, maka dengan adanya kekuatan serta adanya peluang yang dimiliki oleh Kecamatan Jatinangor Kabupaten Sumedang dapat menjadi penunjang dalam mengatasi berbagai ancaman serta kelemahan dalam kegiatan pengelolaan sampah. Berikut dapat diambil simpulan:

1. Membentuk KPSJ sebagai Lembaga Kemasyarakatan yang berada di bawah koordinasi Camat seperti halnya Karang Taruna, LPM dll.

2. Membentuk bank sampah di tiap Desa melalui kerja sama di sektor pemerintah dan swasta sesuai dengan peraturan yang berlaku;

3. Menciptakan inovasi-inovasi terbaru dalam pengelolaan sampah melalui kerja sama sektor internal, sektor swasta, perguruan tinggi serta masyarakat;

4. Menyediakan sarana prasarana pendukung dalam pengelolaan sampah; 
5. Melaksanakan sosialisasi pengelolaan sampah kepada masyarakat;

6. Memfasilitasi pemanfaatan teknologi melalui pembinaan dan pelatihan;

7. Meningkatkan kesadaran masyarakat dalam pengelolaan sampah;

8. Meningkatkan personel dalam pelayanan pengelolaan sampah;

9. Mendukung dan memfasilitasi Komunitas peduli sampah Jatinangor dalam pengelolaan sampah guna menghindari dampak buruk sampah;

10. Memanfaatkan wilayah Jatinangor sebagai kawasan pendidikan dalam pengelolaan sampah;

11. Meningkatkan kerja sama antara pemerintah dan lembaga pendidikan dalam kegiatan pengelolaan sampah rumah tangga;

12. Mencanangkan program sosialisasi pengelolaan sampah rumah tangga dan dampak sampah;

\section{SARAN}

Berdasarkan simpulan dalam penelitian, penulis perlu memberikan masukan berupa saran yang dapat dijadikan sebagai bahan pertimbangan terhadap strategi Camat dalam pengelolaan sampah di Kecamatan Jatinangor Kabupaten Sumedang Provinsi Jawa Barat, sebagai berikut.

1. Membentuk KPSJ sebagai Lembaga Kemasyarakatan yang berada di bawah koordinasi Camat seperti halnya Karang Taruna, LPM dll. bank sampah di tiap Desa melalui kerja sama di sektor pemerintah dan swasta sesuai dengan peraturan yang berlaku;

2. Mengoordinasikan atau memfasilitasi agar dibentuk Bank Sampah di masingmasing Desa di Kecamatan Jatinangor melalui kerja sama di sektor pemerintah dan swasta sesuai dengan peraturan yang berlaku;
3. Mengoordinasikan kepada pihak Perguruan tinggi, sektor swasta, dan masyarakat yang ada di wilayah jatinangor untuk menciptakan inovasiinovasi terbaru dalam pengelolaan sampah;

4. Mengoordinasikan dan mengusulkan kepada pemerintah daerah melalui dinas lingkungan hidup dan kehutanan agar dilengkapi sarana prasarana pendukung dalam pengelolaan sampah;

5. Melakukan sosialisasi pengelolaan sampah kepada masyarakat bekerja sama dengan perguruan tinggi yang ada di wilayah Kecamatan Jatinangor;

6. Melakukan koordinasi dengan pihak terkait agar diberikan pembinaan dan pelatihan kepada masyarakat melalui pemanfaatan teknologi

7. Melakukan pengawasan dalam pengolahan sampah untuk meningkatkan kesadaran masyarakat dalam pengelolaan sampah;

8. Melakukan koordinasi dengan pemerintah daerah atau dinas terkait agar diberikan penambahan personel dalam pelayanan pengelolaan sampah;

9. Memanfaatkan wilayah Jatinangor sebagai kawasan pendidikan dalam pengelolaan sampah;

10. Melakukan koordinasi dan kerja sama antara pemerintah kecamatan dan lembaga pendidikan dalam kegiatan pengelolaan sampah rumah tangga;

11. Mendukung dan memfasilitasi KPSJ (Komunitas Peduli Sampah Jatinangor) dalam pengangkutan dan pengelolaan sampah;

12. Melakukan koordinasi agar diprogramkan sosialisasi pengelolaan sampah rumah tangga dan dampak sampah kepada masyarakat di Kecamatan Jatinangor. 


\section{DAFTAR PUSTAKA}

Arikunto, Suharsimi. 2010. Prosedur Penelitian, Suatu Pendekatan Praktik. Jakarta: PT Rineka Cipta.

PB, Triton. 2011. Manajemen Strategis, terapan Perusahaan dan Bisnis. Jakarta Selatan: Oriza.

Bryson, Jhon M, 2007, Perencanaan Strategi Bagi Organisasi Sosial, Pustaka Belajar: Yogyakarta.

David, R. Freid, 2009, Manajemen Strategi Konsep. Jakarta: Salemba empat.

Hasibuan, Malayu S. P 2007, Manajemen Sumber Daya Manusia Perusahaan, Bandung: PT. Bumi Aksa.

Ismoyo Imam Hendargo.1994. Kamus Istilah Lingkungan. Jakarta: P. T. Bina Rena Pariwira

J. Moleong, Lexy.2014. Metode Penelitian Kualitatif, Edisi Revisi, Bandung: PT Remaja Rosdakarya.

(2011) Metodologi Penelitian Kualitatif Edisi Revisi. Bandung: PT Remaja Rosdakarya

Koswara, E. 2007. Teori Pemerintahan Daerah. Jakarta: IIP Press

Kramadibrata, 2007, Mekanika Batuan, Laboratorium Geomekanika, FIKT-ITB

Nasution, 2011. Metode Research. Jakarta: Bumi Aksara.

Nawawi, Hadari. 2012. Metode Penelitian Bidang Sosial. Yogyakarta: Gajah Mada University Press.

Ridwan HR, 2010. Hukum Administrasi Daerah, Depok: Rajawali press.

R. Terry, George,2006. Prinsip-Prinsip Manajemen. Jakarta: Bumi Aksara.

Rangkuti, Freddy, 2014. Analisis SWOT: Teknik Membedah Kasus Bisnis. Jakarta: Gramedia.

Suryaningrat, Bayu.1981 Wewenang, Tugas dan Tanggung Jawab Camat. Jakarta: CV Pantjuran Tujuh.

Sugiyono. 2012. Metode Penelitian Kuantitatif Kualitatif dan R\&D. Bandung:Alfabeta
2013. Metode Penelitian Pendidikan Pendekatan Kuantitatif, Kualitatif, dan $R \& D$. Bandung: Alfabeta

Sugiyono. (2016) Metode Penelitian Kuantitatif Kualitatifdan Kombinasi (Mixed Methods). Bandung: Alfabeta

Suwartono. 2014. Dasar-dasar Metodologi Penelitian. Yogyakarta: Andi.

Uha, Ismail Nawawi.2014. Manajemen Perubahan teori dan aplikasi pada organisasi publik dan bisnis, Ghalia Indonesia: Bogor

Wasistiono, Ismail dan Fahrurozi, 2009, Perkembangan Organisasi Kecamatan Dari Masa ke Masa, Bandung: Fokus Media.

Wirawan, 2009. Evaluasi Kinerja Sumber Daya Manusia. Jakarta: Salemba empat.

\section{PERATURAN PERUNDANG-UNDANGAN}

Undang-Undang Nomor 18 Tahun 2008 tentang Pengolahan Sampah.

Undang-Undang Nomor 23 Tahun 2014 tentang Pemerintahan Daerah.

Peraturan Pemerintah Republik Indonesia Nomor 08 Tahun 2003 tentang Pedoman Organisasi Perangkat Daerah.

Peraturan Pemerintah Republik Indonesia Nomor 41 Tahun 2007 tentang Organisasi Perangkat Daerah.

Peraturan Pemerintah Republik Indonesia Nomor 19 Tahun 2008 tentang Kecamatan.

Kepmendagri Nomor 158 Tahun 2004 tentang Pedoman Organisasi Kecamatan.

Peraturan Pemerintah (PP) 81 Tahun 2012 tentang pengelolaan sampah rumah tangga dan sampah sejenis rumah tangga.

Peraturan Presiden (Perpres) No. 97 Tahun 2017 tentang kebijakan dan strategi nasional pengelolaan sampah rumah tangga dan sampah sejenis rumah tangga.

Perda Kabupaten Sumedang No. 2 Tahun 2004 tentang Pengelolaan Sampah Rumah Tangga dan Sampah Sejenis Sampah Rumah Tangga di Kabupaten Sumedang.

Surat Edaran Bupati Sumedang Nomor: 658/797/DLHK-2019 tentang himbauan pengurangan penggunaan plastik. 